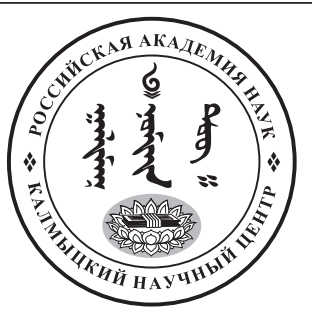

Published in the Russian Federation

Oriental Studies (Previous Name: Bulletin of the Kalmyk Institute

for Humanities of the Russian Academy of Sciences)

Has been issued as a journal since 2008

ISSN: 2619-0990; E-ISSN: 2619-1008

Vol. 13 , Is. 3, pp. 533-545, 2020

DOI: $10.22162 / 2619-0990-2020-49-3-533-545$

Journal homepage: https://kigiran.elpub.ru

УДК 94(470.47).083:578.833.31

DOI: $10.22162 / 2619-0990-2020-49-3-533-545$

\title{
Из опыта борьбы с эпидемическими заболеваниями в Калмыкии: эпидемия чумы 1914 г.
}

\author{
Александр Нармаевич Команджаев ${ }^{1}$, Саглар Евгеньевна Бадмаева ${ }^{2}$ \\ Наталья Петровна Мацакова
}

${ }^{1}$ Калмыцкий государственный университет им. Б. Б. Городовикова-(д. 11, ул. Пушкина, 358000 Элиста, Российская Федерация) доктор исторических наук, профессор, заведующий кафедрой (iD) 0000-0002-7064-7315. E-mail: kalmhistory@yandex.ru

${ }^{2}$ Калмыцкий государственный университет им. Б. Б. Городовикова (д. 11, ул. Пушкина, 358000 Элиста, Российская Федерация кандидат биологических наук, доцент, и. о. заведующего кафедрой iD 0000-0001-7180-7862. E-mail: badmaevase80@gmail.com

${ }^{3}$ Калмыцкий государственный университет им. Б. Б. Городовикова-(д. 11, ул. Пушкина, 358000 Элиста, Российская Федерация) кандидат исторических наук, доцент iD 0000-0001-8586-1632. E-mail: kalmhistory@yandex.ru

(C) КалмНЦ РАН, 2020

(С) Команджаев А. Н., Бадмаева С. Е., Мацакова Н. П., 2020

Аннотация. Введение. Статья посвящена анализу опыта борьбы с чумой в калмыцких степях в 1914 г. Актуальность избранной темы объясняется ее малоизученностью в отечественной историографии. В некоторых работах по истории здравоохранения в Калмыкии имеются фрагментарные упоминания об эпидемических заболеваниях, однако вопрос об эпидемии чумы 1914 г. оказался вне поля зрения. Кроме того, актуальность изучения указанного вопроса объясняется его современным звучанием в наши дни, когда человечество переживает эпидемию коронавируса. Цель и задачи. Цель исследования достаточно конкретна: представить на основе архивных первоисточников, впервые вводимых в научный оборот, картину борьбы с чумой в июне-июле 1914 г. в калмыцких степях. Материаль и методы. Работа основана на применении общенаучных и конкретно-исторических методов, среди которых особое место занимают соблюдение принципа историзма, метода системного анализа и междисциплинарного подхода. Это особенно важно в нашем случае, поскольку речь идет об эпидемическом заболевании в среде кочевого калмыцкого общества в условиях аридных степей более 100 лет 
назад. Источниками при написании данной статьи послужили архивные документы из фонда Управления калмыцким народом в Национальном архиве Республики Калмыкия. Это дела, хранящиеся в описи врачебного отделения и содержащие делопроизводственные материалы о трех эпизодах эпидемии чумы в июне-июле 1914 г., которые позволили нам создать подробную картину произошедшего. Результаты. В статье представлена хронология трагических событий эпидемии чумы в Калмыкии в 1914 г. Установлено, что были произведены все необходимые и оправданные дезинфекционные меры и объявлен в пораженных очагах строгий карантин с изоляцией больных и эвакуацией здоровых людей на безопасное расстояние. Врачи осуществили тотальный осмотр населения соседних с очагами территорий с последующим двухнедельным наблюдением. Bblводы. Благодаря выверенным и слаженным действиям медицинского персонала и административных служб удалось избежать распространения чумы в условиях кочевого образа жизни калмыков. Борьба с чумой в Калмыкии в 1914 г. показала эффективность карантинных и дезинфекционных мероприятий, самоотверженность и профессионализм врачей.

Ключевые слова: Калмыцкая степь, улусы, хотоны, кочевники, эпидемия, эпидемиология, чума, карантин, дезинфекция, эвакуация, грызуны

Благодарность. Исследование выполнено при финансовой поддержке ФГБОУ ВО «Калмыцкий государственный университет им. Б. Б. Городовикова» в рамках научного проекта «Исторический опыт Прикаспийских регионов по противодействию массовым эпидемиям и эпизоотиям в XIX - начале XX века: на примере Калмыкии», 2020 г.).

Для цитирования: Команджаев А. Н., Бадмаева С. Е., Мацакова Н. П. Из опыта борьбы с эпидемическими заболеваниями в Калмыкии: эпидемия чумы 1914 г. // Oriental Studies. 2020.

T. 13. № 3. C. 533-545. DOI: 10.22162/2619-0990-2020-49-3-533-545

UDC 94(470.47).083:578.833.31

DOI: $10.22162 / 2619-0990-2020-49-3-533-545$

\title{
Experience of Combating Epidemics in Kalmykia: a Case Study of the 1914 Plague Outbreak
}

\author{
Alexandr N. Komandzhaev ${ }^{1}$, Saglar E. Badmaeva², Natalia P. Matsakova ${ }^{3}$ \\ ${ }^{1}$ Gorodovikov Kalmyk State University (11, Pushkin St., Elista 358000 Elista, Russian Federation) \\ Dr. Sc. (History), Professor, Head of Department \\ (iD) 0000-0002-7064-7315. E-mail: kalmhistory@yandex.ru
}

${ }^{2}$ Gorodovikov Kalmyk State University (11, Pushkin St., Elista 358000 Elista, Russian Federation) Cand. Sc. (Biology), Associate Professor, Acting Head of Department

iD 0000-0001-7180-7862. E-mail: badmaevase80@gmail.com

${ }^{3}$ Gorodovikov Kalmyk State University (11, Pushkin St., Elista 358000 Elista, Russian Federation) Cand. Sc. (History), Associate Professor

iD 0000-0001-8586-1632. E-mail: kalmhistory@yandex.ru

(C) KalmSC RAS, 2020

(C) Komandzhaev A. N., Badmaeva S. E., Matsakova N. P., 2020

Annotation. Introduction. The article analyzes the anti-plague efforts launched in the Kalmyk Steppe in 1914. The topic remains understudied in domestic historiography, and only a few papers dealing with Kalmykia's public healthcare history contain occasional mentions of some epidemic diseases. So, the 1914 plague epidemic has been overlooked as well. And the study proves even more relevant nowadays when humanity is globally facing COVID-19 threats. Goals. The paper specifically aims to provide insight - on the basis of primary archival sources newly introduced into scientific circulation — to the struggle against plague in the Kalmyk Steppe in June and July of 1914. 
Materials and Methods. The work employs general scientific and specifically historical methods, with emphasis be laid on the principle of historicism, method of systemic analysis, and interdisciplinary approach. The latter is particularly important when it comes to examine an epidemic in a nomadic society across arid territories - and all that took place over 100 years ago. The article deals with archival documents stored at the National Archive of Kalmykia (Kalmyk People's Administration collection). Those files included in the catalogue of Public Healthcare Department contain materials on three episodes of plague in June and July of 1914, and prove instrumental in reconstructing the actual events in detail. Results. The article chronicles the dramatic vicissitudes of the 1914 plague epidemic in Kalmykia, and shows that all required and justified disinfection measures were assumed, e.g., a strict quarantine was established in the affected areas, sick individuals were isolated and healthy ones evacuated to a safe distance. The doctors were conducting a total inspection of the population in areas adjacent to those of outbreaks, which was followed by two more weeks of observations.

Keywords: Kalmyk Steppe, ulus, khoton, nomads, epidemics, epidemiology, plague, quarantine, disinfection, evacuation, rodents

Acknowledgements. The reported study was funded by Gorodovikov Kalmyk State University, project title 'Caspian Regions. Historical Experience of Combatting Mass Epidemics and Epizootics, $19^{\text {th }}-$ Early $20^{\text {th }}$ Centuries: a Case Study of Kalmykia', 2020.

For citation: Komandzhaev A. N., Badmaeva S. E., Matsakova N. P. Experience of Combating Epidemics in Kalmykia: a Case Study of the 1914 Plague Outbreak. Oriental studies. 2020. Vol. 13(3): 533-545. (In Russ.). DOI: 10.22162/2619-0990-2020-49-3-533-545

\section{Введение}

Проблема борьбы с эпидемическими заболеваниями в Калмыкии относится к неизученным вопросам в отечественной историографии. Первые опыты по научному изучению природы некоторых заболеваний у кочевого калмыцкого населения предпринял выдающийся ученый И. И. Мечников, посещавший калмыцкие степи в $1870-е$ гг. и в 1911 г. [Мечников 1959].

В начале XX в. длительное время врачом Управления калмыцким народом работал П. В. Пальмирский, написавший статью об особенностях борьбы с эпидемическими заболеваниями в калмыцких улусах [Пальмирский 1909]. В 1920-е гг. врач У. Д. Душан опубликовал статью о постановке здравоохранения в Калмыкии, в том числе представил некоторые заметки о методах народной медицины у калмыков [Душан 1922].

О системе здравоохранения в начале $\mathrm{XX}$ в. имеется небольшой раздел в трехтомной истории Калмыкии, изданной в 2009 г. [Команджаев 2009].

В 2018 г. защищена кандидатская диссертация М. В. Бадугиновой по истории здравоохранения Калмыкии, первая глава которой посвящена дореволюционной медицине, в частности народной и тибетской медицине, а также формированию улусной сети здравоохранения [Бадугинова 2018].

В современной российской историографии обращает на себя внимание статья Д. В. Михеля, в которой автор представил обстоятельный обзор развития эпидемиологической науки в России в связи с возникавшими эпидемиями чумы, в том числе в регионе Нижнего Поволжья (в станице Ветлянской в 1878-1879 гг., унесшей жизни 434 человек, и в с. Колобовка в 1899 г., где погибли 23 человека) [Михель 2008]. Автор обратил внимание на выдающийся вклад микробиолога и эпидемиолога, академика Д. К. Заболотного, доказавшего роль грызунов в распространении чумы, тем самым высказав идею об эндемичности заболевания в прикаспийских степях.

Большой интерес также вызывает статья Н. Н. Блохиной об истории противочумной службы в России в рассматриваемый нами период [Блохина 2012].

Из зарубежных исследователей на проблему борьбы с эпидемическими заболеваниями в Калмыкии в первой половине XIX в. обратил внимание Т. Иноуэ, его статья «О разработке „Положения об оспопрививании в калмыцких улусах (1839)“»» опубликована в сборнике материалов Астраханских краеведческих чтений [Иноуэ 2013]. 
Что касается исторического опыта борьбы с эпидемическими заболеваниями в Калмыкии в конце XIX - начале XX в., то данный вопрос оказался вне поля зрения историков. Актуальность избранной темы, помимо ее неизученности в исторической науке, определяется еще и современным состоянием нашего общества, находящегося в условиях эпидемии коронавируса со всеми вытекающими отсюда последствиями. Поэтому обращение авторов к заявленной теме на основе архивных материалов, впервые вводимых в научный оборот, на наш взгляд, может помочь в познании уроков прошлого.

\section{Материалы и методы}

Работа основана на применении синтеза общенаучных и конкретно-исторических методов, среди которых особое место занимают соблюдение принципа историзма, метода системного анализа и междисциплинарного подхода. Это особенно важно в нашем случае, поскольку речь идет об эпидемическом заболевании в среде своеобразного кочевого калмыцкого общества в условиях аридных степей более 100 лет назад. Содержание исследования основано на использовании архивных документов из фонда Управления калмыцким народом в Национальном архиве Республики Калмыкия. Это дела, хранящиеся в описи врачебного отделения и содержащие делопроизводственные материалы о трех эпизодах эпидемии чумы в июне-июле 1914 г., которые позволили нам создать подробную картину произошедшего [НА РК. Ф. 9. Оп. 8. Д. 103].

\section{Первая вспышка чумы в «Аршан- Тебе» и борьба с нею}

В июне 1914 г. в Астрахани начал публиковаться еженедельный бюллетень отдела народного здравия губернской земской управы о ходе чумных и подозрительных по чуме заболеваний в Астраханской губернии. В бюллетене № 1 о ходе заболевания чумой за 1-7 июня сообщалось о том, что в урочище «Аршан-Тебе» Шебенеровского аймака Малодербетовского улуса заболели чумой и скончались 5 человек [НА РК. Ф. 9. Оп. 8. Д. 103. Л. 1].

В этом же номере бюллетеня имеется подробное описание событий, связанных с заболеванием, авторами которого являлись замещавший должность председателя гу- бернской земской управы А. Сурменев и заведующий отделом народного здравия этой управы врач М. Рафес. В описании говорится о том, что эпидемия чумы началась в урочище «Аршан-Тебе» в начале июня (обнаружилась 4 июня). Это урочище находилось в 12 верстах от с. Обильное, в 25 верстах от с. Садовое, в 50 верстах от улусной ставки в c. Тундутово и в 57 верстах от станции Гнило-Аксайская Владикавказской железной дороги. Указанные села возникли во второй половине XIX в. в рамках плана заселения калмыцких дорог, в них проживало русско-украинское переселенческое крестьянское население. Села в административно-территориальном отношении входили в состав Черноярского уезда Астраханской губернии.

Заболевание появилось в калмыцком кочевье, где располагался хотон из 7 кибиток с 36 жителями. Вначале заболело двое, затем число заболевших дошло до пяти. Болезнь сопровождалась сильным жаром, кашлем и в двух случаях - кровавой мокротой. Поскольку в течение короткого времени (4 дня) заболело и умерло 5 человек, то это обстоятельство обеспокоило всех жителей как данного, так и соседних хотонов, которые об этом сообщили старшине Шебенеровского аймака, а последний 6 июня известил попечителя Малодербетовского улуса. 7 июня вечером в урочище прибыли попечитель улуса и участковый улусный врач Э. Хара-Даван ${ }^{1}$ с фельдшером. Врач по результатам осмотра тел и бесед с родственниками покойных установил клиническую картину, на основе которой сразу же определил диагноз смертельной болезни чума. В тот же день жители четырех кибиток, членами семей которых являлись пятеро заболевших и умерших, были вымыты «зеленым мылом» ${ }^{2}$ и продезинфицированы

\footnotetext{
1 Эренджен Хара-Даван после окончания медицинского факультета Казанского университета в 1911 г. был назначен врачом Малодербетовского улуса. Во многих делопроизводственных документах изучаемого периода его фамилия написана слитно - Харадаван [НА РК. Ф. 9. Оп. 8. Д. 27. Л. 15, 18].

2 Зелёная или бурая смесь на мыльной клеевой основе. Безопасное, эффективное, универсальное средство, обладает антибактериальными, инсектицидными и фунгицидными свойствами. В его состав входят калийные соли жирных кислот, животные жиры, вода и натуральные растительные масла.
} 
в устроенном под баню помещении, переодеты в чистое белье и помещены в трех кибитках на месте обнаружения очага. В одну из них были поселены 8 человек, непосредственно контактировавшие с больными. Жители оставшихся трех кибиток, которые по предварительному осмотру врачом Э. Хара-Даваном были признаны здоровыми, переселены (эвакуированы) в другое урочище, но на другой день также были вымыты, продезинфицированы и переодеты. Среди них оказалось 3 человек с повышенной температурой, которые были изолированы в отдельной кибитке. В этот же день, 8 июня, прибыли в урочище вызванные телеграммой от улусного попечителя врач-бактериолог из Астрахани Аристархова ${ }^{3 *}$ и врач из Заветненской ${ }^{4}$ бактериологической лаборатории Суворов*, которые произвели вскрытие двух тел и взяли пробы мокроты у нового больного. На основе мазков и чистой выделенной культуры бактериологами был поставлен диагноз - легочная чума. После этого врач Аристархова уехала на место службы в Астрахань, а врач Суворов на месте очага занялся обследованием сусликов и грызунов в пораженном и соседних участках [НА РК. Ф. 9. Оп. 8. Д. 103. Л. 3-3об.].

9 июня на очаг приехал из Астрахани врач Управления калмыцким народом С. Залкинд 5 . На следующий день, 10 июня, прибыл из Астрахани для руководства противоэпидемическими мероприятиями врачебный инспектор Астраханской губернии М. Милославский, вместе с которым приехали командированные на очаг врач Цацинского участка В. Пиотровский и медик-студент 4 курса Токарев*.

Если 9 июня врач Э. Хара-Даван осматривал с термометрированием и поименной учетной записью жителей окружающих хотонов, то 10-11 июня это продолжили

3 Здесь и далее, если не указаны инициалы, то в архивных документах данных сведений не имеется.

${ }^{4}$ К территории, подведомственной Заветненской бактериологической лаборатории, относились Аксайский, Ремонтненский, Заветненский, Кормовской и Садовский врачебные участки Черноярского уезда, а также Малодербетовский улус Калмыцкой степи Астраханской губернии.

${ }^{5}$ В делопроизводственных документах изучаемого периода фамилия врача С. Р. Залкинда написана с мягким знаком - Залькинд.
В. Пиотровский и Токарев. Параллельно врачи С. Залкинд, Э. Хара-Даван и врачебный инспектор М. Милославский вместе с фельдшерами и санитарами производили лечение и уход за больными, а также занимались дезинфекцией и эвакуацией здоровых лиц. Новые заболевшие чумой (3 человека) скончались 9-10 июня, и, как отметили авторы статистических отчетов и текстового описания событий А. Сурменев и М. Рафес, «с той поры новых больных не наблюдалось» [НА РК. Ф. 9. Оп. 8. Д. 103. Л. 3об.].

11 июня вечером в числе эвакуированных жителей обнаружилось 3 человека с высокой температурой, которые сразу же были переведены в отдельную кибитку. Bce трое после бактериологического изучения оказались «не чумными», а также у отселенного от прочих с повышенной температурой санитара диагностировали приступ малярии. Все предпринятые действия сопровождались довольно масштабными мероприятиями по изоляции, переселению и дезинфекции людей и помещений.

4 кибитки, в которых проживали скончавшиеся от чумы первые больные, по решению врачей были сожжены вместе с вещами и бытовой утварью после предварительной оценки всего имущества, составившей большую по тем временам сумму 3200 руб. Эта мера была вынужденной и вызвана желанием врачей радикально уничтожить первый очаг чумы в Калмыцкой степи. Впоследствии для эффективной дезинфекции вещей и одежды стали использовать присланный в Калмыкию аппарат «Гелиос» [НА РК. Ф. 9. Оп. 8. Д. 103. Л. 3об.].

Оценка уничтоженных кибиток и имущества производилась с целью последующей денежной компенсации потерь пострадавшим лицам. 12 июня в чумной очаг прибыли командированные дополнительно врачи Кушинский и Ефимов с 3 фельдшерами и 6 санитарами. В тот же день приехали астраханский вице-губернатор Н. Максимов и врач М. Рафес. Последний был командирован от земства для ознакомления с мероприятиями на месте. На общем собрании всего медицинского персонала под председательством Н. Максимова были обсуждены все обстоятельства дела и выработан план дальнейших действий. 
Согласно плану, общее руководство всеми мероприятиями возлагалось на врачебного инспектора губернии М. Милославского, начальником оцепления всего пораженного района был назначен исправник Черноярского уезда, заведование хозяйственной частью было поручено попечителю Малодербетовского улуса.

Э. Хара-Давану поручили лечение больных, Кушинскому - дезинфекцию участка, П. Ефимову — эвакуационно-изоляционные мероприятия, В. Пиотровскому - обследование населения в соседних местностях. Суворову поручили продолжить бактериологическое обслуживание очага и исследование грызунов. Для этого попросили привезти из Астрахани походную лабораторию или микроскоп для исследования [НА РК. Ф. 9. Оп. 8. Д. 103. Л. Зоб.].

По мнению М. Рафеса, эпидемия чумы в урочище «Аршан-Тебе» была первым подобным случаем за обозримый период наблюдений в Калмыцкой степи. Ранее эти случаи фиксировались во Внутренней Киргизской орде и различных уездах Астраханской губернии. По результатам изучения ситуации с грызунами бактериологами Аристарховой и Суворовым стало ясно, что данная вспышка чумы была животного, а не завозного происхождения и связана с чумной эпизоотией у сусликов, которых калмыки часто употребляли в пищу в жареном виде. В архивном деле имеется записка, составленная, по всей видимости, Суворовым об изучении грызунов [НА РК. Ф. 9. Оп. 8. Д. 103. Л. 11].

Согласно инструкции комиссии по изучению чумы при императорском институте экспериментальной медицины, врачи вскрыли на месте 26 сусликов и тушканчиков, и у трех сусликов и одного тушканчика были получены в Заветненской бактериологической лаборатории чумные культуры. Один из трех больных сусликов и один тушканчик были найдены павшими вблизи того места, где стояла кибитка первого заболевшего в урочище «Аршан-Тебе» [НА РК. Ф. 9. Оп. 8. Д. 103. Л. 11]. Так был определен источник заражения. Рядом с хотоном наблюдалось большое скопление сусликов и «порядочный мор» среди них [НА РК. Ф. 9. ОП. 8. Д. 103. Л. Зоб.]. При этом «чумные» суслики обнаружились в $100 \mathrm{ca}-$ женях (чуть более 200 м) от очага. В связи с этим по рекомендации М. Рафеса земская управа губернии командировала в очаг двух эпидемических фельдшеров из Астрахани для наблюдения.

После 11 июня в пораженной зоне новых больных не наблюдалось. Бюллетень № 2 за 8-15 июня констатировал смерть от чумы трех человек, а всего с начала эпидемии - восемь человек [НА РК. Ф. 9. Оп. 8. Д. 103. Л. 5]. В своей аналитической справке А. Сурменев и М. Рафес в этом бюллетене указали, что карантинный срок завершается 16 июня и «сейчас производятся мероприятия по ликвидации этого чумного очага» [НА РК. Ф. 9. Оп. 8. Д. 103. Л. 4].

В бюллетене № 3 за 16-23 июня была напечатана информация о том, что чумной очаг в урочище «Аршан-Тебе» ликвидирован [НА РК. Ф. 9. Оп. 8. Д. 103. Л. 5]. Но это заявление оказалось преждевременным. Через неделю в бюллетене № 4 за 24-30 июня последовало сообщение о том, что в урочище «Аршан-Тебе» 26 июня обнаружены 2 новых случая заболевания чумой, из которых один заболевший умер. По клинической картине болезнь диагностировал 26 июня заведующий наблюдательным пунктом в урочище на период карантинного двухнедельного срока (срок карантина истекал 30 июня) врач М. Ефимов. Бактериологически его диагноз был подтвержден Аристарховой и Суворовым 30 июня [НА РК. Ф. 9. Оп. 8. Д. 103. Л. 7].

В бюллетене № 5 от 1-7 июля сообщалось, что в урочище «Аршан-Тебе» умер от чумы второй из двух заболевших (первый умер раньше) [НА РК. Ф. 9. Оп. 8. Д. 103. Л. 10]. В описательной записке А. Сурменева и М. Рафеса к информации в бюллетене № 4 об этом случае сказано следующее. В урочище «Аршан-Тебе» в 1,5 верстах от первичного очага 25 июня на садово-овощной плантации заболела татарка со всеми признаками бубонной чумы, которая была осмотрена врачом П. И. Ефимовым и умерла 27 июня. При вскрытии трупа обнаружены, кроме явлений бубонной чумы, еще признаки вторичной легочной чумы, также подтвержденной бактериологически. 30 июня в той же татарской семье среди изолированных заболела еще одна девушка 17 лет, которая к концу отчетной недели оставалась живой [НА РК. Ф. 9. Оп. 8. Д. 103. Л. 7об.]. 
Продолжение этой трагичной истории описано уже в бюллетене № 5: 17-летняя больная Шамшидинова умерла 2 июля и после смерти от чумы доктора П. И. Ефимова больше заболеваний в этом районе не наблюдалось. На месте очага был оставлен наблюдательный отряд в составе врачей Полыковского и Архангельского с медицинским персоналом, а весь прежний медперсонал, контактировавший с П. Ефимовым, после положенного карантина выехал в места постоянной службы.

В пятом номере бюллетеня был также опубликован некролог о погибшем враче П. И. Ефимове. Ввиду того, что имя и деятельность П. И. Ефимова практически неизвестны читателям, приведем текст некролога полностью. «3 июля 1914 года в урочище „Аршан-Тебе“" скончался от легочной чумы окончивший 10 семестров медицинского факультета Саратовского Николаевского университета Петр Иванович Ефимов, 23 лет от роду. Покойный был уроженцем г. Астрахани и по окончании местной гимназии поступил в Саратовский университет. Летом этого года он прослушал 10 семестров медицинского факультета и, не сдавши еще государственных экзаменов, записался во врачебном отделении в число лиц, желающих ехать на борьбу с чумой. Сын учителя начальной школы, покойный имел отца и мать с 5 детьми школьного возраста, и, являясь их поддержкой и опорой в будущем, он добывал себе средства к существованию личным заработком. В 1913 г. П. И. Ефимов работал в одном из отрядов по исследованию и ловле грызунов, организованных профессором Д. К. Заболотным в целях изучения эпидемиологии чумы, а 10 июня текущего года он был командирован врачебным отделением на правах врача в урочище „Аршан-Тебе“, куда прибыл 12 июня и где провел благополучно первую вспышку чумы. Оставленный во главе наблюдательного отряда он, полный сил и энергии, завершал объезд окрестных хотонов и обнаружил новую больную, при исследовании которой он и заразился. Мир праху твоему, самоотверженный врач и честный товарищ» [НА РК. Ф. 9. Оп. 8. Д. 103. Л. 10об.].

Далее в этом же номере бюллетеня есть описание этого трагического эпизода, который мы также приводим здесь с некоторыми стилистическими поправками. «Срок деятельности наблюдательного отряда на урочище „Аршан-Тебе“ истекал 30 июня, и П. Ефимов, совершая свой заключительный объезд калмыцких хотонов, 26 июня обнаружил в татарской семье, работавшей на бахче, больную женщину, заболевшую чумой еще 20 июня. Первый осмотр больного П. Ефимов производил лично. Полагая, что у нее бубонная чума и не подозревая о том, что болезнь перешла в легочную стадию, врач выслушивал больную без средств предосторожности (без респиратора). 27 июня к больной приехал врач С. Суворов, который в присутствии П. Ефимова произвел клиническое исследование мокроты и крови. Позже больная умерла. Вскрытие тела показало изменения в легких и в левой подмышечной области. Болезнь, начавшаяся в бубонной форме, уже перешла в легочную стадию. 30 июня из членов этой татарской семьи заболела еще девушка 17 лет, скончавшаяся 2 июля. В своем письме к родителям от 30 июня врач П. Ефимов написал: «Я боялся, не заразился ли я от умершей, теперь срок истекает, кажется - нет». Это письмо оказалось последним. 1 июля утром П. Ефимов заболел сам: температура утром была 38,6, к вечеру поднялась до 39,6 градусов. В этот же день вызвали бактериолога из с. Заветное. 2 июля утром у П. Ефимова температура поднялась до 40 градусов, наблюдалась мокрота с кровью, хрипы в груди, больной начал бредить. Он был без сознания, но, приходя в себя, осознавал свою неминуемую смерть. Больше всего беспокоился о своих родителях, которых он содержал. 3 июля больной умер в 13.40» [НА РК. Ф. 9. Оп. 8. Д. 103. Л. 11].

Бюллетень № 6 от 8-15 июля 1914 г. констатировал ликвидацию очага чумы в урочище «Аршан-Тебе» Однако продолжились работы по наблюдению с термометрированием соседних с названным урочищем крестьянских сел и хуторов. Жители хутора «Жарков» вначале отказывались от термометрирования, но врачу Садовского врачебного участка Ф. И. Елиной удалось их убедить в необходимости обследования. В ходе обследования был обнаружен еще один очаг чумы в с. Садовом, где от этой болезни умерли 2 человека. Об этом сообщили в бюллетене № 7 от 16-23 июля. Следующий бюллетень № 8 уже проинформировал 
о ликвидации чумного очага в с. Садовом [НА РК. Ф. 9. Оп. 8. Д. 103. Л. 15-20].

Командированный от губернской земской управы врач-эпидемиолог И. Д. Пембек не обнаружил в Малодербетовском улусе среди калмыцкого населения «подозрений на чуму» [НА РК. Ф. 9. О. 8. Д. 103. Л. 11об.].

\section{Борьба со вспышками чумы в Бага- цохуровском улусе}

В этот же период, в июне 1914 г., помимо трагических событий в урочище «Аршан-Тебе» Малодербетовского улуса, произошли еще две вспышки заболевания чумой в Калмыцкой степи. В бюллетене № 2 за 8-15 июня ниже данных об эпидемии чумы в «Аршан-Тебе» появилась информация о заболевании чумой в урочище «Кекшин» Зюневского аймака Багацохуровского улуса. Здесь 12 июня заболели 4 человека, которые умерли через несколько дней. Клинически диагноз установил 15 июня улусный фельдшер, бактериологически данный диагноз был подтвержден 17 июня врачом Денисовой из Астраханский бактериологической лаборатории [НА РК. Ф. 9. Оп. 8. Д. 103. Л. 3]. Бюллетень № 3 за 16-23 июня сообщил, что в урочище «Кекшин» скончались от чумы еще 3 человека [НА РК. Ф. 9. Оп. 8. Д. 103. Л. 5].

В текстовом отчете о случившемся в урочище «Кекшин» авторы А. Сурменев и врач М. Рафес отметили следующее. 12 июня в урочище «Кекшин» Зюневского аймака Багацохуровского улуса в 12 верстах от казачьей станицы Михайловская Енотаевского уезда, в 35 верстах от г. Енотаевска умерла девочка от болезни, сопровождавшейся жаром на протяжении 5 дней. Сама по себе болезнь и смерть не вызвала у окружающих особого беспокойства, но ночью того же 12 июня скончался отец девочки, оспопрививатель Калмыцкой степи, перед смертью попросивший специально известить обо всем попечителя улуса. У получившего данное известие попечителя возникли подозрения об эпидемическом характере заболевания. Воспользовавшись присутствием в Енотаевске (здесь находилась ставка Багацохуровского улуса) врача-бактериолога Денисовой, занимавшейся обследованием сусликов в уезде, попечитель с ней отправился на место события. Вскры- тие обоих тел и последовавший за этим бактериологический анализ биоматериалов не дали ясного однозначного ответа. Но, когда 15 июня умер от подобной болезни брат оспопрививателя (старик 60 лет), бактериолог уверенно заявила о возможности чумы. Окончательный диагноз был установлен 17 июня после смерти мальчика подросткового возраста от болезни. Его тело осмотрел Енотаевский уездный врач Полыковский и обнаружил типичные для чумы два «бубона» на шее и в подмышечной впадине и две «пустулы» на груди и руке, что характерно для кожной формы чумы. Бактериологическое исследование мазков и вскрытие тела, произведенные Денисовой и Полыковским, подтвердило диагноз - бубонная чума. Все случаи заболевания прошли без наблюдения медицинского персонала. Уездный врач Полыковский прибыл в урочище «Кекшин» 16 июня (после смерти мальчика), 17 июня прибыл окончивший 10 семестров медицинского факультета студент-медик Федоров, 18 июня - помощник врачебного инспектора губернии Г. Абрамов и студент-медик 3 курса Лебедев с фельдшерами и санитарами.

В урочище располагался хотон из 4 кибиток с 15 жителями, из которых 4 умерло. Оставшиеся жители хотона (11 человек) были по распоряжению попечителя улуса изолированы. Все они после мытья были продезинфицированы, переодеты в новую одежду 19 июня после получения эпидинвентаря и дезинфицирующих средств. С того же дня под руководством Г. Абрамова началось систематическое обследование с термометрированием населения окрестных урочищ. К имеющемуся медицинскому персоналу в урочище «Кекшин» добавились врач Управления калмыцким народом С. Залкинд, врач Харахусовского улуса Д. Бровкин, студенты-медики Мельников и Токарев. У врачей возникли подозрения, что заболел чумой местный гелюнг, принимавший участие в похоронах оспопрививателя, но тревога оказалась ложной.

19 июня приезжали вице-губернатор Н. Максимов и от земской управы М. Рафес. Так как недалеко от урочища «Кекшин» находились казачьи станицы и крестьянские села, то в станице Михайловская обследование населения провел врач 1 округа Астраханского казачьего войска Кергер, в стани- 
це Косикинская - врач 2 округа Воронин с фельдшерами. Оба обследовали казачье население как этих, так и других близлежащих станиц. Жителей соседних крестьянских сел Федоровка, Ивановка и Николаевка, отстоявших от урочища «Кекшин» в 20-30 верстах, осматривали врач Золотухинского врачебного участка Тихомиров с фельдшером. В связи с тем, что больше больных чумой в пораженном участке не наблюдалось, с 24 июня чумной очаг сочли ликвидированным и оставили на месте лишь наблюдательный пункт на двухнедельный срок [НА РК. Ф. 9. Оп. 8. Д. 103. Л. 5об.].

Бюллетень № 4 за 24-30 июня, проинформировавший о второй вспышке чумы на урочище «Аршан-Тебе», о чем мы писали выше, также сообщил о возникновении еще одного чумного очага в урочище «Гюбя» Багацохуровского улуса и смерти трех человек из четырех заболевших. По клинической картине установил диагноз прибывший из Харахусовского улуса врач Бровкин, что и было подтверждено бактериологом Денисовой 29 июня [НА РК. Ф. 9. Оп. 8. Д. 103. Л. 7].

По архивным первоисточникам нам удалось установить хронологию и содержание событий. 24 июня 1914 г. пунктовый полицейский стражник Гринков письменно доложил попечителю Багацохуровского улуса В. Сагайдаку о том, что он обнаружил в урочище «Зергенте» 10 больных, нуждавшихся в лечении, и попросил срочно направить фельдшера. Поскольку улусный фельдшер находился в отъезде, то на место события в урочище «Зергенте» был направлен врач Харахусовского улуса Д. Бровкин. Врач, осмотрев больных, установил, что они заболели возвратным тифом и находятся в стадии выздоровления [НА РК. Ф. 9. Оп. 8. Д. 104. Л. 1].

Пользуясь случаем и желая определить эпидемическую ситуацию в районе, Д. Бровкин обследовал соседние с урочищем «Зергенте» участки. В урочище «Гюбя» он обнаружил в хотоне трех больных в трех разных кибитках, один из которых умер, а двое находились в крайне тяжелом состоянии: «сознание несколько помрачено, взгляд неподвижный, температура у одного 40, у другого - 39,6 градусов, паховые и подмышечные железы увеличены и очень болезненны» [НА РК. Ф. 9. Оп. 8. Д. 104.
Л. 3]. Врач по данной клинической картине установил, что все больны чумой. 25 июня он в служебной записке попросил заведующего чумным очагом в урочище «Кекшин» (там оставался наблюдательный пункт) немедленно прибыть в урочище «Гюбя» и захватить с собой бактериолога для уточнения диагноза [НА РК. Ф. 9. Оп. 8. Д. 104. Л. 3].

В тот же день в Астрахани состоялось заседание врачебного совета в Управлении калмыцким народом под председательством старшего врача Управления С. Залкинда с приглашением попечителя Багацохуровского улуса В. Сагайдака. На этом заседании было решено командировать в урочище «Гюбя» врачей Залкинда и Полыковского, бактериолога Денисову, фельдшера, двух санитаров и двух полицейских стражников и взять с собой необходимые дезинфицирующие средства и комплекты белья для 10 человек. Что же касается наблюдательного пункта в урочище «Кекшин», то было предложено там оставить студента-медика Лебедева на правах врача. Находившиеся в пункте врач Федоров и студент-медик Токарев должны были продолжать обследование населения в соседних с урочищем «Кекшин» участках по ранее составленному плану [НА РК. Ф. 9. Оп. 8. Д. 104. Л. 4-5].

По прибытии в урочище «Гюбя» на следующий день врачебная комиссия обнаружила трех умерших (20-летняя женщина и двое мужчин в возрасте 19 и 20 лет) - по одному в каждой из трех кибиток. По словам родственников погибших, они скончались, проболев не более трех дней. Недалеко от этих кибиток в отдельно устроенных жилищах под телегами, покрытыми кошмами, ютились две семьи. В отдельном «шалаше» на более отдаленном расстоянии расположилась семья из двух человек: вдова с 20-летней больной дочерью. Было поручено врачам Денисовой и Полыковскому произвести патолого-анатомическое вскрытие тел умерших с последующим бактериологическим исследованием [НА РК. Ф. 9. Оп. 8. Д. 104. Л. 6-7]. Тем временем врач Бровкин в результате осмотра места эпидемии и опроса сородичей заболевших установил, что умершие 6-7 дней назад питались мясом павшего верблюда, а его шкуру продали проезжавшим чумакам (торговцам). Оставшаяся часть этого мяса предположительно была отправлена в Багацохуровский хурул. 
Вечером в день прибытия в урочище «Гюбя» состоялось очередное, 3-е, заседание врачебного совета в составе врачей Залкинда, Бровкина, Полыковского, бактериолога Денисовой и попечителя улуса В. Сагайдака, на котором прозвучала информация о результатах вскрытия тел умерших. Бактериолог доложила, что по результатам вскрытия тел установлен диагноз болезни умерших - бубонная чума [НА РК. Ф. 9. Оп. 8. Д. 104. Л. 8-9].

На этом заседании было принято решение: тела умерших кремировать, все население хотона после санобработки переселить (эвакуировать) в безопасное место, за заболевшей 20-летней женщиной установить наблюдение, разрешив ухаживать за ней матери. Врачебный совет обратился к администрации губернии с просьбой командировать 20 полицейских стражников для устройства охранных постов по периметру очага, командировать дополнительно еще одного врача, трех фельдшеров, четырех санитаров, выслать необходимое количество дезинфицирующих средств, а также выделить автомобиль для нужд очага и средства для найма (аренды) кибиток для эвакуации населения, жилья для стражников и медицинского персонала, помещений для канцелярии и склада, для найма пяти конных и пеших вестовых, двух водовозов и двух пастухов для эвакуации скота. На заседании были распределены обязанности имеющихся врачей следующим образом: Залкинд осуществляет наблюдение и лечение заболевших, Полыковский - надзор за эвакуацией населения и скота, Бровкин руководит дезинфекционными мероприятиями, студенты-медики Токарев и Лебедев обследуют жителей соседних хотонов. Было рекомендовано внимательно наблюдать за двумя семьями, кочевавшими рядом с семьями заболевших за месяц до случившегося [НА РК. Ф. 9. Оп. 8. Д. 104. Л. 13-13об.].

В этот же день врач С. Залкинд, взявший на себя обязанности заведующего чумным очагом в урочище «Гюбя», направил докладную записку астраханскому губернатору с просьбой о выделении финансовых средств, автомобиля, дезинфицирующих средств (сулема, карболовая кислота, «зеленое мыло» и др.), а также необходимое количество марли, ваты, 6 халатов, 12 тюфяков и 26 полотенец. Кроме того, было решено установить постоянную связь с близлежащим селом Никольским. Сразу же были переселены из чумного очага в другое место три семьи в составе 13 человек [НА РК. Ф. 9. Оп. 8. Д. 104. Л. 16].

На четвертом заседании врачей чумного очага были заслушаны доклады Полыковского об эвакуации людей и скота, Бровкина - о дезинфекционных мероприятиях. По этим докладам приняли решение: уничтожить (сжечь) кибитки умерших, кошмы, меха и часть имущества по описи, остальные вещи продезинфицировать и отдать владельцам. Полыковскому поручили выяснить, кому из торговцев была продана шкура павшего верблюда. Бровкин должен был прояснить ситуацию с Багацохуровским хурулом, куда, по сведениям, передали часть мяса павшего верблюда. 28 июня на очередном заседании врачебного совета очага врач Бровкин доложил, что все служители Багацохуровского хурула здоровы и отрицают факт получения ими мяса павшего верблюда. Врач Полыковский сообщил, что никто из эвакуированных не знает, кому была продана шкура павшего верблюда. Поскольку в этом районе имелись выздоравливающие от возвратного тифа, было решено просить Управление калмыцким народом о выделении 100 руб. для раздачи на закупку продуктов наиболее бедным из них [НА РК. Ф. 9. Оп. 8. Д. 104. Л. 22].

Следующее заседание врачебного совета состоялось 2 июля 1914 г. На нем был заслушан доклад врача Полыковского о состоянии дел у эвакуированного населения. Врач сообщил, что у всех переселенных калмыков регулярно осуществляется термометрия (у всех этот показатель в пределах нормы) и 3 июля истекает положенный 5-дневный срок эвакуации, после чего при благополучном исходе необходимо жителей хотона вернуть в прежние места кочевания, кроме одного человека, чей 5-дневный срок карантина еще не прошел. Речь шла о женщине, ухаживавшей за скончавшейся от чумы дочерью. Врач Бровкин и исполнявший должность врача студент-медик Лебедев доложили о результатах обследования населения вокруг урочища «Гюбя» до границ соседних улусов Калмыцкой степи. Больных не обнаружено. Были обследованы хотоны в семи урочищах (Цаган-Темян, Хамыр-Гелюнг и др.) с населением 250 чело- 
век в 54 семьях. Руководитель чумного очага Залкинд сообщил о распоряжении астраханского губернатора от 1 июля командировать студентов-медиков Лебедева и Токарева в связи с вторичной вспышкой чумы в урочище «Аршан-Тебе» Малодербетовского улуса. Попечитель Багацохуровского улуса $\mathrm{Ca}$ гайдак проинформировал врачебное совещание о том, что шкура павшего верблюда продана местному торговцу А. Рыжкову. На заседании постановили: врачу Полыковскому продолжить обследование населения в северном направлении от урочища «Гюбя», попечителю улуса Сагайдаку поручили выяснить у А. Рыжкова, кому тот продал верблюжью шкуру. Помещение, в котором А. Рыжков хранил шкуру, врачебный совет обязал продезинфицировать [НА РК. Ф. 9. Оп. 8. Д. 104. Л. 37].

Залкинд в тот же день направил положенные телеграммы с информацией о состоянии дел в очаге по трем адресам: астраханскому губернатору, в Управление калмыцким народом и врачебному инспектору губернии. В них он сообщил, что новых заболевших чумой в очаге не имеется, дезинфекция одежды и бытовой утвари у жителей хотона завершена, студенты Лебедев и Токарев выехали в урочище «Аршан-Тебе», подсобное помещение А. Рыжкова, где хранилась шкура павшего верблюда, продезинфицировано, а шкура продана в г. Черный Яр [НА РК. Ф. 9. Оп. 8. Д. 104. Л. 40].

На заседании врачебного совета 3 июля Полыковский доложил о завершении 5-дневного срока эвакуации людей и их возвращении на прежние места кочевания. У оставшейся в эвакуации женщины карантинный срок истекает 5 июля, и она также будет возвращена в свой хотон. Также он доложил об отсутствии новых больных в хотонах севернее очага. На заседании огласили текст телеграммы бактериолога Денисовой о том, что в окрестностях Зюневского аймака (на территории которого находились урочища «Кекшин» и «Гюбя») обнаружены три «чумных» грызуна (два суслика и один тушканчик). В связи с этим она рекомендовала установить режим наблюдения за всеми жителями Багацохуровского улуса. Был также обсужден вопрос об общем состоянии дел в системе здравоохранения улуса. В результате на заседании было решено: ходатайствовать через Управление калмыц- ким народом в земский отдел МВД о скорейшем открытии в течение полугодия двух фельдшерских пунктов в Багацохуровском улусе. Здание одного из фельдшерских пунктов в Баруновском аймаке уже было построено за счет калмыцкого общественного капитала, но пункт так и не начал свою деятельность. Также врачи на заседании рекомендовали преобразовать приемный покой Багацохуровского улуса в г. Енотаевске во врачебный пункт и ввести должность врача в штат улуса [НА РК. Ф. 9. Оп. 8. Д. 104. Л. 44-44об.].

11-е заседание врачей в урочище «Гюбя» состоялось 5 июля. Полыковский сообщил, что последний из эвакуированных возвращен в свой хотон. Залкинд объявил о том, что фельдшеры и санитары в связи с завершением эпидемии уходят в положенный 5-дневный карантин. В урочище создается наблюдательный пункт сроком на две недели в составе врача, фельдшера, двух санитаров и двух полицейских стражников. Заведующим наблюдательного пункта в урочище «Гюбя» назначается и. о. врача Федоров, который должен приехать 8 июля после закрытия наблюдательного пункта в урочище «Кекшин». Временно до его приезда был назначен заведующим наблюдательного пункта врач Бровкин. Также на заседании сообщили о найденной шкуре павшего верблюда, которую было решено сжечь [НА РК. Ф. 9. Оп. 8. Д. 104. Л. 50].

На 12-м заседании врачей, состоявшемся 6 июля с присутствием прибывшего заведующего калмыцким народом В. Локтева и попечителя Багацохуровского улуса В. Сагайдака, заслушали доклад ветеринарных врачей Балашова и Спасского, которые прибыли в урочище «Гюбя» с целью осмотра верблюдов и установления возможной связи между болезнями верблюдов и чумой у людей. Их сообщения были приняты к сведению. 7 июля С. Залкинд отправил телеграммы в губернские инстанции с сообщением о том, что осмотр верблюдов ветеринарами Балашовым и Спасским завершен, и больных животных не обнаружено, врач Полыковский выехал в чумной очаг в урочище «Аршан-Тебе» Малодербетовского улуса, заведующий калмыцким народом уехал в Астрахань к месту службы [НА РК. Ф. 9. Оп. 8. Д. 104. Л. 56]. 
В тот же день был составлен акт комиссии с подписями всех врачей чумного отряда об уничтожении личной одежды медицинского персонала (трех врачей, четырех фельдшеров и пяти санитаров), которая «пришла в негодность от частой дезинфекции», и о выдаче денежной компенсации за уничтоженное. В архивном деле врачебного отряда также приложена докладная записка врача Бровкина с результатами термометрии у жителей хотонов в семи урочищах (Цекер-Болдан, Мазан-Худук, Гувелин-Худук и др.) численностью 483 человек (имеется поименный список). Также Бровкин указал, что один человек на урочище «Мазан-Худук» с температурой 38 градусов болеет возвратным тифом [НА РК. Ф. 9. Оп. 8. Д. 104. Л. 69].

На 13-м заседании врачей 9 июля врач Федоров доложил о результатах двухнедельного врачебного наблюдения за жителями урочища «Кекшин» и об отсутствии новых случаев заболевания чумой. В итоге на заседании врачей решили прекратить работу наблюдательного отряда в урочище «Кекшин» и поручили Федорову приступить к исполнению обязанностей заведующего наблюдательным пунктом в урочище «Гюбя». Врачу Бровкину разрешили выехать в Харахусовский улус к месту своей работы [НА РК. Ф. 9. Оп. 8. Д. 104. Л. 75].

Последнее, 14-е, заседание врачей в урочище «Гюбя» состоялось 10 июля 1914 г. Было решено работу наблюдательного пункта осуществлять до 19 июля. После заседания руководитель чумного отряда С. Р. Залкинд выехал в Астрахань и приступил к исполнению своих обязанностей в качестве старшего врача Управления калмыцким народом, попечитель улуса В. Сагайдак отправился в г. Енотаевск, где находилось Багацохуровское улусное управление [НА РК. Ф. 9. Оп. 8. Д. 104. Л. 77].

\section{Выводы}

Анализ конкретного материала об эпидемии чумы в Калмыцкой степи летом 1914 г. подтвердил мнение ученых о «животном» происхождении заболевания и роли степных грызунов в его распространении. В каждом из трех урочищ, где произошли вспышки чумы, была обнаружена чума у сусликов и тушканчиков. Вместе с тем обращают на себя внимание социальные причины болезни, о которых не только знали медики и чиновники, но и говорили в обществе: бедность и низкий уровень жизни, неблагополучное в санитарно-эпидемиологическом отношении состояние калмыцкого кочевого быта. Это явственно прослеживается в представленных материалах: «ели мясо павшего верблюда», соорудили под телегами жилье, «где ютились две семьи», в «шалаше» проживала мать с больной чумой дочерью. К сожалению, в изучаемый период отсутствовали эффективные способы лечения. Поэтому все случаи заболевания чумой в 1914 г. в калмыцких улусах завершились летальным исходом. В лучшем случае врачи осуществляли паллиативное лечение в целях облегчения состояния больных.

Вместе с тем калмыцкий опыт борьбы с чумой показал основополагающую позитивную роль карантинных и дезинфекционных мероприятий: болезнь не распространилась на другие урочища степи. Эта борьба с чумой продемонстрировала высочайший нравственный уровень общества, что видно по самоотверженным и профессиональным действиям медицинского персонала. Всем врачам, фельдшерам и санитарам было свойственно ясное понимание служебного долга: в чумные очаги приехали не только представители медицинского персонала калмыцких улусов, но и врачи из соседних уездов губернии, участковые врачи из близлежащих сел, а также студенты-старшекурсники медицинских факультетов. Врачи П. Ефимов (погибший в борьбе с чумой), Э. Хара-Даван, В. Бровкин, С. Залкинд и другие, первыми вставшие на пути смертельной болезни, показали образцы мужества и героизма. Невозможно оценить самопожертвование оставшейся вдовой женщины, которая ухаживала за умирающей от чумы единственной 20-летней дочерью, находясь в карантинной зоне в условиях полной изоляции. Обращает на себя внимание готовность всего государственного механизма империи обеспечить борьбу с эпидемией чумы в калмыцких улусах всеми материальными средствами и людскими ресурсами. 


\section{Источники}

НА РК - Национальный архив Республики Калмыкия.

\section{Литература}

Бадугинова 2018 - Бадугинова М. В. Здравоохранение Калмыкии в конце XIX - первой половине XX века: автореф. дис. ... канд. ист. наук. Грозный, 2018. 29 с.

Блохина 2012 - Блохина Н. Н. К истории деятельности противочумной службы в России в начале XX века // Эпидемиология и инфекционные болезни. 2012. № 1. С. 56-61.

Душан 1922 - Душан У. Д. Медико-санитарная часть в Калмыцкой степи // Ойратские известия. 1922. № 3-4. С. 99-107.

Иноуэ 2013 - Такехико Иноуэ. О разработке «Положения об оспопрививании в калмыцких улусах» (1839): по материалам переписки И. С. Тимирязева и П. Д. Киселева) // Мат-лы конф. «Астраханские краеведческие чтения». Вып. 5 / отв. ред. А. А. Курапов.

\section{References}

Baduginova M. V. Kalmykia's Public Healthcare System: Late $19^{\text {th }}-$ Mid-20 ${ }^{\text {th }}$ Centuries. Cand. Sc. (history) thesis abstract. Grozny, 2018. 29 p. (In Russ.)

Blokhina N. N. History of the activity of Russia's anti-plague service in the early $20^{\text {th }}$ century. Epidemiology and Infectious Diseases. 2012. No. 1. Pp. 56-61. (In Russ.)

Dushan U. D. Medical and sanitary service in the Kalmyk Steppe. Oyratskie izvestiya. 1922. No. 3-4. Pp. 99-107. (In Russ.)

Inoue Takehiko. Developing Smallpox Vaccination Regulations for Kalmyk-inhabited districts (1839): a case study of epistolary intercourse between I. Timiryazev and P. Kiselev. In: Kurapov A. A. (ed.) Astrakhan Regional History and Lore Readings. Vol. 5. Astrakhan:

\section{Sources}

National Archive of the Republic of Kalmykia

Астрахань: Сорокин Р. В., 2013. С. 191-195.

Команджаев 2009 - Команджаев А. Н. Система здравоохранения в начале XX в. // История Калмыкии с древнейших времен до наших дней: в 3 т. Т. 3. Элиста: Герел, 2009. С. 576581.

Мечников 1959 - Мечников И. И. Изменения по заболеваемости туберкулезом в калмыцких степях // Мечников И. И. Собр. соч. М.: Медгиз, 1959. Т. 10. С. 181-191.

Михель 2008 - Михель Д. В. Чума и эпидемиологическая революция в России: 1897-1914 // Вестник Евразии. 2008. № 3. С.142-164.

Пальмирский 1909 - Пальмирский П. В. Об условиях борьбы с чумой, холерой и оспой в Калмыцкой степи Астраханской губ. // Известия общества астраханских врачей. 1909. № 2. C. 1-7.

\section{R. Sorokin, 2013. Pp. 191-195. (In Russ.)}

Komandzhaev A. N. Public healthcare system in the early $20^{\text {th }}$ century. In: Maksimov K. N., Ochirova N. G. et al. (eds.) History of Kalmykia: From Earliest Times to the Present Days. In 3 vols. Vol. 3. Elista: Gerel, 2009. Pp. 576-581. (In Russ.)

Mechnikov I. I. Kalmyk Steppe: changes in tuberculosis rates. In: Mechnikov I. I. Complete Works. Moscow: Medgiz, 1959. Vol. 10. Pp. 181-191. (In Russ.)

Mikhel D. V. Plague and epidemiological revolution in Russia: 1897-1914. Vestnik Evrazii. 2008. No. 3. Pp. 142-164. (In Russ.)

Palmirsky P. V. Kalmyk Steppe of Astrakhan Governorate: circumstances of combating plague, cholera and smallpox revisited. Izvestiya obshchestva astrakhanskikh vrachey. 1909. No. 2. Pp. 1-7. (In Russ.) 